N.W. Spencer, Jr. (U of Utah, 1979): "The Diplomatic History of Iraq, 1920-1932"

R.L. Staab (U of Utah, 1980): "The Timar System in the Eyalet of Rumeli and the Nahiye of Dimetoka in the Late 15th and 16th Centuries"

Adel Allouche ( $U$ of Utah, 1980): "The Origins and Development of Ottoman /Safavid Conflict (906-962/1500-1555)"

\title{
Ph.D. Dissertations in Progress
}

S.l. Gellens (Columbia U) : "Social History at the Provincial Level: The 'Ulama' of Pre-Fatimid Egypt, 800-1000 C.E."

$R$. al-Nassir ( $U$ of Michigan): "Wahabbi Influence on Maghrib Religious Thought"

J. Beinin (U of Michigan): "Labor and Politics in Egypt, 1936-1952"

V. Egger (U of Michigan): "Salama Musa in Modern Egyptian Thought

$R$. Eloul ( $U$ of Michigan): "Sedentarization and Political Adaptation of Pastoral Tribesmen"

A. Fituri (U of Michigan): "Trans-Saharan Trade"

P. Laughlin (U of Michigan): "Ibn Abi'l-Dunya's K. Qivā'l-Dayf"

H. Mohtadi ( $U$ of Michigan): "The Effect of Foreign investment on income Distribution in Iran"

R. Pannbacker ( $U$ of Michigan): "The Levantine Community of Pittsburg"

W. Rollman ( $U$ of Michigan): "Moroccan Military Organization and Reform, 1860-1912"

T. Suzuki (U of Michigan): "The White Revolution, The Malik-Ra iyat System, and Rice Production in Northern Iran"

Susan Ziadeh (U of Michigan): "Shibbi Shunayil and the Arab Renaissance"

M. Marcus (NYU): "Life History and Cultural Form in Morocco: A Study of Self-Concepts in the Context of Social Change"

Y. al-Tabba (NYU): "Architecture and Ideology under Nur al-Dín, 1146-1173"

D. Alexander (NYU): "The Sword of Islam"

Carol Bier (NYU): "Dionysiac Imagery in the Art of Iran"

$R$. Eng (NYU): "Mu in Musavvir: A Safavid Miniature Painter"

Linda Komaroff (NYU): "Timurid Metalwork: A Stylistic, Technical and Historical Survey"

S. Peterson (NYU): "Shi ${ }^{\text {ism }}$ and Late Iranian Art"

Barbara Schmidtz (NYU): "The Herat School of Painting in the Safavid Period"

H. Spevak (NYU): "The Idea of Cosmic Kingship in the Iconography of Early Islam"

June Taboroff (NYU): "The Shrine Complex at Bistam, Iran: Setting, Architecture and Patronage"

M.J. Monahan (NYU): "The Structure and Nature of the Intra-Asian Caravan Trade between Safavid Iran and Mughal India in the 16th and 17th Centuries"

Linda K. Steinmann (NYU): "Shah ${ }^{C_{A b b a s}} \mathrm{I}$ and the Reorientation of the Persian Silk Trade, 1600-1629"

R. Brann (NYU): "Form and Structure of the Secular Poetry of Moshe ibn Ezra"

Jennie Fitzgerald (NYU): "The Role of the Qizilbash, 995-1011/15871603: The Early Reign of "Abbas I"

Amina S. Gomaa (NYU): "Tractate Kiddushin with an Arabic Translation: An Introduction and a Commentary"

Jo-Ann Gross (NYU): "The Naqshabandi Order in the Late Timurid Period: A Study in Religious Power and Prestige" 
Linda Knezevich (NYU): "Administrative and Social History of the Syrian Christian Church"

S. Motia-Esfahani (NYU): "The Intellectual Development of Sayyed Hasan Taqizadeh"

Nadine Posner (NYU): "Muslim Conquest and Early Administration in Northern Mesopotamia"

R. Schoem (NYU): "Modernization of Damascus in the 20th Century as Seen Through Changes in its Population"

W. Shpall (NYU): "The Varieties of Love in Nizami's Khosrow and Shirin"

K. Simpson (NYU): "Common Daily Phraseology in Contemporary Persian"

Diana Lieb (NYU): "Conflict and Conflict Resolution Process: A Case Study of the Arab-Israeli Conflict, 1973-1979"

F. Shafik (NYU): "The Press and the Politics of Independent Egypt, 1922-1970: Comparative Analysis of Causal Relationships"

A. Riedlmayer (Princeton): "The Anatomy of an Ottoman Campaign: Causes and Uses of the 1610 Eastern Expedition"

Caroline Beeson (Princeton): "Religious Leaders in 16th-Century Iran" Diana Burrough (Princeton): "China's Relations with the Arab World, 1949-1980"

1. Blay (Princeton): "Political, Administrative and Social Problems of Syria, 700-940 A.D."

L. Conrad (Princeton): "Plague and Society in the Early Medieval Near East"

R. Hattox (Princeton): "Coffeehouses and Urban Society in the Ottoman Lands in the 15 th and 16th Centuries"

V.R. Holbrook (Princeton): "A History of Great Turkish Ney Players" M. Kramer (Princeton): "Islamic Conferences"

Marilyn Mayers (Princeton): "Development of Psychiatry in Modern Egypt"

L. Miller (Princeton): "Arabic Dialectics"

O. Soysal (Princeton): "Turkey's Policy Toward the Arab-Israeli Question"

R. Vaughan (Princeton): "Islam and the African Traditions"

J. Yarrison (Princeton): "Force as an Instrument of Policy: European Military Incursions into the Maghrib, 1000-1355"

Y. Arat (Princeton): "Political Participation of Turkish Women"

T. Mitchell (Princeton): "Egyptian Society and its University, 1906-36"

M. Robbins (Princeton): "The Strategy of Innocence: Political Resocialization of Middle Eastern Jews in Israel"

Miriam Petruck (UC/Berkeley): "Body Part Terminology in Hebrew and Arabic: A Study in Comparative Lexical Semantics"

D. Justice (UC/Berkeley): "Form and Notion in Arabic and European Languages"

A. Barnea (UC/Berkeley): "Linguistic Analysis of the City Dialect of Gaza"

P. Bray (UC/Berkeley): "Creation of Soviet Socialist Literature in Central Asia"

H. Davis (UC/Berkeley): "Critical Analysis of Early Arabic Lexicography"

Elaine Coombs-Schilling (UC/Berkeley): "Authority and Social Control in a Moroccan Regional Trading Community: A Study in Continuity and Change"

L. Michalak (UC/Berkeley): "Weekly Markets and Socio-Economic

Change in Rural Tunisia: A Regional Analysis"

S. Sowoyan (UC/Berkeley): "Pre-Islamic Arabic Epic Oral Poetry" 
R. Monroe (UC/Berkeley): "Contribution of Amin Rihani to Arabic Literature in the Field of Creative Writing"

Kristina Nelson (UC/Berkeley): "Art of Reciting the Koran"

J. Pirnazar (UC/Berkeley): "Study of Social and Cultural Aspects in Iran Between World War I and World War II"

D. Prochaska (UC/Berkeley): "Colonialism Triumphant: White Settlers in Colonial Algeria, 1870-1919"

M. Zussman (UC/Berkeley): "From State Cooperatives to Family Farms: A Comparative Study of Land Reform Experiments in Tunisia"

Audri Durshlag (UC/Berkeley): "On Parallels from Scriptural Models to Modern"

J. Fleck (UC/Berkeley): "Modern Hebrew Literature: A Search for a Hero from Mandels to A.B. Vshestua"

M. Sadiq (UC/Berkeley): "Archetypal Patterns in the Hebrew and Arabic Novel"

R. Adams (UC/Berkeley): "Local Institutions and Agricultural Development in Egypt"

K. Beyoghlow (UC/Berkeley) : "Syrian Political Leadership"

M. Sabuncuoglu (UC/Berkeley): "Language Reform and National Development in Turkey"

Judith Jarrow (U of Utah): "Feminist Tradition in Tunisia"

R.F. Zeidner (U of Utah): "The Tricolor over the Taurus - 1918-22"

A. Maberry ( $U$ of $W$ ): "Ibn al-Tayyib's Commentary on the Categories of Aristotle"

J. Othman ( $U$ of $W$ ): "A Critique of Instructional Materials for Near Eastern Studies"

Rosalind Gwynne ( $U$ of $W$ ): "The Tafsīr of Abū CAlī al-Jubbā'" Judy Fetters ( $U$ of $W$ ): "The Risale-i Evsaf-i Istanbul of Latifí"

Sandra Layman ( $U$ of $W$ ): "Turkish/Greek Folk Music"

Irene Markoff ( $U$ of $W$ ): "Conceptual Systems in Turkish Folk Music" Azade Seyhan ( $U$ of $W$ ): "Turkish and German Drama"

Nanette Pyne ( $U$ of $W$ ): "Economic Changes in Seljuq Khuzestan: An Investigation into the Archaeological, Geographical and Historical Sources"

D. Sbait ( $U$ of $W$ ): "The Improvised, Sung Folk Poetry of the Pales"tinians"

M. Shakib_( $U$ of $W$ ): "The Influence of Arabic Literature on Hamidi's Maqāmāt"

M. Guerssel ( $U$ of $W$ ): "Toward a Lexical Approach to Phonological Description"

W. Scott (U of W) : "Concepts of War in Arabic Drama: Four Contemporary Egyptian Plays"

S. Ward (Yale) : "Islamic Law and Practice on the Construction and Repair of Non-Muslim Houses of Worship: A Monograph by Taq $\bar{i}$ al-Din al-Subkí.

\section{Appointments and Promotions}

Peter Garretson

Barbara Green

Isaac Kikawada

Kristina Nelson

Jaleh Pirnazar

Gerhard Bowering

Renata Holod

David Jacobson

Ajaj Jarrouj
- Asst. Prof. of History, Florida State University.

- Tenure Track, Religious Studies, Dominican Coll.

- Lecturer, N.E. Studies, UC/Berkeley.

- Tenure Track, Ethnomusicology/N.E. Studies, $U$ of Texas, Austin.

- Acting Instructor, N.E. Studies, UC/Berkeley.

- Assoc. Prof. of Religious Studies, U/Pennsylvania.

- Assoc. Prof. of Art History. $U$ of Pennsylvania.

- Prof., Hebrew Languages \& Literature, Li/Penn.

- Asst. Prof. of Oriental Studies, $U$ of Penn. 